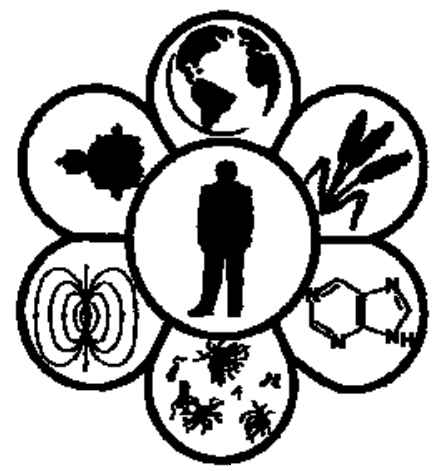

Вісник Дніпропетровського університету. Біологія, медицина Vìsnik Dnìpropetrovs'kogo unìversitetu. Serìa Bìologîa, medicina Visnyk of Dnipropetrovsk University. Biology, medicine

Vìsn. Dnìpropetr. Unìv. Ser. Bìol. Med. 2014. 5(1), 3-6. doi:10.15421/021401

ISSN 2310-4155 print ISSN 2312-7295 online

www.medicine.dp.ua

\title{
Оцінка цитотоксичної дії антигістамінних препаратів лоратадину та дезлоратадину з використанням тест-об'єкта - сперміїв бугаїв
}

\author{
О.Б. Кузьмінов ${ }^{1}$, Д.Д. Остапів ${ }^{2}$, Т.А. Альохіна ${ }^{1}$ \\ ${ }^{I}$ Львівський наиіональний медичний університет імені Данила Галииького, Львів, Украӥна \\ ${ }^{2}$ Інститут біологї̈ тварин НААН, Львів, Україна
}

\begin{abstract}
Оцінено цитотоксичний вплив фармакологічних субстанцій для виробництва вітчизняних антигістамінних препаратів лоратадину та дезлоратадину. Як тест-об'єкт використано суспензію сперміїв бугая. Проби сперми ділили на контрольну (розріджену фосфатно-сольовим буфером) і дослідні 3 додаванням у фосфатно-сольовий буфер лоратадину у дозах $1 / 500 \mathrm{LD}_{50}(12,3$ мг), $1 / 100 \mathrm{LD}_{50}\left(61,5\right.$ мг) та $\mathrm{LD}_{50}\left(6150\right.$ мг) і дезлоратадину $1 / 500 \mathrm{LD}_{50}\left(1,25\right.$ мг), 1/100 $\mathrm{LD}_{50}\left(6,25\right.$ мг) та LD $\mathrm{L}_{50}(625$ мг). Визначали виживання сперміїв до припинення прямолінійного поступального руху у збереженій за температури $+2 \ldots+5{ }^{\circ} \mathrm{C}$ спермі, дихальну активність (ex tempore) - полярографічно у термостатованій комірці $\left(38,5^{\circ} \mathrm{C}\right)$ об'ємом 1,0 мл 3 автоматичною реєстрацією перебігу процесу потенціометром; відновну активність - потенціометрично з використанням системи відкритих мікроелектродів, які вставляли в термостатовану полярографічну комірку. Виживання сперміїв у спермі за дії лоратадину нижче показників контролю на 10,0-30,0\%, за дії дезлоратадину - на 5,3-52,7\%. Дихальна та відновна активність сперми під вливом лоратадину знижуються відповідно на 20,5-61,5\% і 80,0-98,0\%, під впливом дезлоратадину відповідно на 16,2-80,7\% і 12,0-60,0\% порівняно 3 контролем.
\end{abstract}

Ключові слова: лоратадин; дезлоратадин; цитотоксичний вплив; спермії бугаїв

\section{Evaluation of cytotoxic action of antihistamines - desloratadine and loratadine - using bulls spermatozoa as a test object}

\author{
O. Kuzminov ${ }^{1}$, D. Ostapiv ${ }^{2}$, T. Alekhina ${ }^{1}$ \\ ${ }^{I}$ Danylo Halytskyy Lviv National Medical University, Lviv, Ukraine \\ ${ }^{2}$ Institute of Animal Biology of NAAS, Lviv, Ukraine
}

\begin{abstract}
Antihistamines with active ingredients of loratadine and desloratadine are produced by Ukrainian pharmaceutical industry. According to the law, ther are assessed for their potential danger to human health and the environment, including alternative test objects. Evaluation has been carried out with regard to cytotoxic effect of pharmacological substances (loratadine and desloratadine) using the bull sperm suspension as test objects, standardized and highly sensitive to toxic substances. Sperm was divided into the control sample (dissolved by phosphatebuffered saline) and the investigated sample. Loratadine was added to phosphate-buffered saline in doses of $1 / 500 \mathrm{LD}_{50}(12.3 \mathrm{mg})$, $1 / 100 \mathrm{LD}_{50}(61.5 \mathrm{mg})$ and $\mathrm{LD}_{50}(6150 \mathrm{mg})$. Desloratadine doses were $1 / 500 \mathrm{LD}_{50}(1.25 \mathrm{mg}), 1 / 100 \mathrm{LD}_{50}(6.25 \mathrm{mg}) \mathrm{and} \mathrm{LD}_{50}(625 \mathrm{mg})$. Survival of spermatozoa was defined until termination of rectilinear forward movement in sperm intacted at $+2 \ldots+5{ }^{\circ} \mathrm{C}$. Respiratory activity (ex tempore) was defined in $1.0 \mathrm{ml}$ thermostated cell (temperature of $38.5^{\circ} \mathrm{C}$ ) by polarography with the automatic registration of process flow by potentiometer; restorative activity was defined potentiometrically, using the open microelectrodes that were inserted in thermostated polarographic cell. Survival of spermatozoa in the sperm under the impact of loratadine in doses of $1 / 500 L_{50}$ and $1 / 100 \mathrm{LD}_{50}$ is respectively $136.0 \pm 26.2$ hours and $144.0 \pm 19.6$ hours. Adding $\mathrm{LD}_{50}$ dose of loratadine reduced survival to $112.0 \pm 26.2$ hours, which is lower than the control $(160.0 \pm 26.1$ hours), respectively, by 10.0-15.0 and 30.0\%. Loratadine reduces the respiratory activity of sperm: in the dose of $1 / 500 \mathrm{LD}_{50}$ by $20.5 \%$, in the dose of $1 / 100 \mathrm{LD}_{50}$ - by $43.6 \%$, and that of $100 \mathrm{LD}_{50}-$ by $61.5 \%$ compared to the control.
\end{abstract}

Львівський начіональний медичний університет імені Данила Галищького, вул. Пекарська, 69, Львів, 79010, Украӥна. Lviv National Medical University of Danylo Halytskyy, Pekarska str., 69, Lviv, 79019, Ukraine.

Tel.: +38-032-260-09-06.E-mail: toxcentr@rambler.ru

Інститут біологї̈ тварин НААН, вул. Василя Стуса, 38, Львів, 79034, Україна.

Institute of Animal Biology of NAAS, V. Stusa str., 38, Lviv, 79019, Ukraine.

Tel.: +38-032-270-23-89, E-mail: inenbiol@mail.lviv.ua 
Restorative sperm activity under the impact of the loratadine reduced by $84.0 \%$ (dose of $1 / 500 \mathrm{LD}_{50}$ ), $98.0 \%$ (dose of $1 / 100 \mathrm{LD}_{50}$ ), $80.0 \%$ $\left(\right.$ dose $\mathrm{LD}_{50}$ ) compared to controls. The survival of spermatozoa in the sperm under desloratadine action in the dose of $1 / 500 \mathrm{LD}_{50}$ is $144.0 \pm$ 19.6 hours $\left(10.0 \%\right.$ reduction compared with the control $-152.0 \pm 23.6$ hours), in the dose of $1 / 100 \mathrm{LD}_{50}-136.0 \pm 26.1$ hours $(15.0 \%$ reduction), in the dose of $\mathrm{LD}_{50}-72.0 \pm 19.6$ hours (30.0\% reduction). The intensity of oxygen consumption by sperm reduced by $16.2 \%$ when adding desloratadine in the dose of $1 / 500 \mathrm{LD}_{50}$, by $38.8 \%$ in the dose of $1 / 100 \mathrm{LD}_{50}$ and by $80.7 \%$ - in the dose of $\mathrm{LD}_{50}$, compared with the control. Inhibition of respiratory activity is accompanied by decreasing in the transport of protons and electrons from spermatozoa into the extracellular medium, that manifests decreasing of reconstructive activity when the dose of desloratadine is $1 / 500 \mathrm{LD}_{50}($ by $12.0 \%$ ), $1 / 100 \mathrm{LD}_{50}$ (by $40.0 \%$ ) and $\mathrm{LD}_{50}$ (by $60,0 \%$ ) compared with the control.

Keywords: loratadine; desloratadine; cytotoxic effect; bull sperm

\section{Вступ}

Антигістамінні препарати 3 діючими речовинами лоратадин і дезлоратадин займають одну з провідних позицій за обсягом споживання на українському фармацевтичному ринку. Широке використання вказаних препаратів зумовлене їх властивостями (гальмування виходу утворених і заново синтезованих медіаторів на рівні клітини (Genovese et al., 1997)) і доведеною ефективністю у випадку лікування алергічного риніту та кропивниці, відсутністю негативного впливу на репродуктивну функцію (McIntyre et al., 2003), стійкістю лікарських форм (Karen et al., 2013). Виявлено також позитивний вплив лоратадину як модифікатора радіаційної відповіді під час лікування раку (Soule et al., 2010). Дія лоратадину та дезлоратадину на метаболізм клітин опосередкована низькою здатністю до взаємодії $з$ мембранозв'язаним фосфорильованим глікопротеїном (170 кДа; P-GP) порівняно 3 іншими антигістамінними препаратами (Wang Erjia et al., 2003).

Серед зарубіжних виробників на українському фармацевтичному ринку представлені препарати виробництва США, Великобританії, Індії, Угорщини, Швейцарії, Канади (Zaychenko et al., 2012). Випуск генеричних версій розпочато на ПАТ «Лекхім-Харків» (м. Харків), ПАТ «Фармак» (м. Київ), ПАТ «Київмедпрепарат» (м. Київ), ПАТ «Фармацевтична фірма “Дарниця"» (м. Київ). Промислове виробництво зумовлює проведення токсикологічної оцінки впливу фармакологічних субстанцій лоратадину та дезлоратадину на працівників з обгрунтуванням допустимого рівня вмісту препаратів в об’єктах довкілля.

За правилами нового Європейського законодавства, яке набуло чинності у 2007 році, до переліку обов'язкових методів оцінки потенційної небезпечності хімічних речовин для здоров'я людини та навколишнього середовища повинні бути включені методи оцінки токсичності на альтернативних тест-об' єктах (Dmytrukha, 2013; Enayetallah et al., 2013).

Поширені альтернативні методи досліджень із використанням рухливості статевих клітин як тест-об'єкта (Almova and Begieva, 2012; Nemkova et al., 2013).

Високою чутливістю до токсичних речовин володіє суспензія сперміїв бугая, яка широко використовується у практиці штучного запліднення і є стандартизованою. Переваги даного методу дозволили поширити його в медицині та ветеринарії під час токсикологічних дослідженнь (Muzyka et al., 2011).

Мета статті - з'ясувати наявність цитотоксичної дії лоратадину та дезлоратадину за тривалістю виживання сперміїв та інтенсивністю окисних процесів у спермі бугаїв.

\section{Матеріал і методи досліджень}

Лоратадин - етиловий ефір-4-(8-хлор-5,6-дигідро11Н-бензо-[5,6]циклогепта-[1,2-b]піридин-11-іліден)-1піперидинкарбонової кислоти. Синоніми - ВероЛоратадин, Кларитин, Ломелан, Лоратин, Кларотадин. CAS № 79794-75-5. Емпірична формула - $\mathrm{C}_{22} \mathrm{H}_{23} \mathrm{~N}_{2} \mathrm{ClO}_{2}$, молекулярна маса - 382,9. За зовнішнім виглядом це порошок білого кольору, помірно розчинний у воді, дуже мало розчинний у гексані, практично нерозчинний у спирті та хлороформі. Температура плавлення $+131 \ldots+137{ }^{\circ} \mathrm{C}$. Вміст основної речовини $-98,5-101,0 \%$ у перерахунку на суху речовину. Агрегатний стан у повітрі - аерозоль дезінтеграції. Виробник субстанції «Farmachem SA Chem Limited», Індія. Середньосмертельна доза $\left(\mathrm{LD}_{50}\right)$ для білих щурів становить 6150 мг/кг.

Дезлоратадин - 8-хлор-6,11-дигідро-11-(4-піперидинілиден)-5Н-бензо[5,6]циклогепта[1,2-b]піридин. Синоніми - Делот, Кларамакс, Кларинекс, Ларинекс, Лоратек, Лордестин, НеоКларитин, Едем, Еридез, Еріус, Еслотин. CAS № 100643-71-8. Емпірична формула - $\mathrm{C}_{19} \mathrm{H}_{19} \mathrm{ClN}_{2}$, молекулярна маса $-310,8$. За зовнішнім виглядом це порошок від білого до кремового кольору, помірно розчинний у воді, розчинний в етиловому та метиловому спирті, диметилсульфоксиді, хлороформі. Температура плавлення $+155 \ldots+160{ }^{\circ} \mathrm{C}$. Вміст основної речовини 98,0-102,0\% у перерахунку на суху речовину. Агрегатний стан у повітрі: аерозоль дезінтеграції. Виробник субстанції - «Cadila Healthcare LTD», Індія. LD $_{50}$ для білих щурів - $625 \mathrm{мг/кг.}$

Для досліджень використовували свіжоотримані еякуляти бугаїв таких фізіологічних характеристик: об' $\mathrm{м}$ 4-5 мл, концентрація сперміїв 0,7-0,9 × 109 клітин/мл, кількість живих статевих клітин - 70-85\%. Для оцінювання та характеристики дії фармакологічних субстанцій проби сперми ділили на контрольну, розріджену фосфатно-сольовим буфером (ФСБ; $\mathrm{NaCl}-0,8$ г, $\mathrm{KCl}-0,02$ г, $\mathrm{Na}_{2} \mathrm{HPO}_{4}-0,11$ г, $\mathrm{KH}_{2} \mathrm{PO}_{4}-0,02$ г, $\mathrm{MgCl}_{2}-0,01$ г, $\mathrm{H}_{2} \mathrm{O}-$ до 100 мл) та дослідні, із додаванням у ФСБ лоратадину у дозах $1 / 500 \mathrm{LD}_{50}(12,3 \mathrm{мг}), 1 / 100 \mathrm{LD}_{50}(61,5 \mathrm{мг})$ та $\mathrm{LD}_{50}$ (6150 мг) і дезлоратадину - 1/500 LD 50 (1,25 мг), 1/100 $\mathrm{LD}_{50}\left(6,25\right.$ мг) та $\mathrm{LD}_{50}(625$ мг). Визначали виживання сперміїв (год) до припинення прямолінійного поступального руху у збереженій за температури $+2 \ldots+5{ }^{\circ} \mathrm{C}$ спермі, дихальну активність (ex tempore) - полярографічно (нгатом $O / 0,1$ мл сперми $(\mathrm{C}) \times \mathrm{xв})$ у термостатованій комірці (температура $38,5^{\circ} \mathrm{C}$ ) об'ємом 1,0 мл 3 автоматичною реєстрацією перебігу процесу потенціометром; відновну активність - потенціометрично $(\mathrm{mV} / 0,1$ мл $\mathrm{C} \times \mathrm{xв})$ із використанням системи відкритих мікроелектродів, які вставляли у термостатовану полярографічну комірку 
(Shtolts et al., 1980). Різницю між вибірками вважали статистично вірогідною за $P<0,05$ (Plokhinskiy, 1970).

\section{Результати та їх обговорення}

Виживання сперміїв у спермі за дії лоратадину в дозах $1 / 500 \mathrm{LD}_{50}$ та $1 / 100 \mathrm{LD}_{50}$ майже однакове $(136,0$ 144,0 год), а у разі додавання лоратадину в дозі $\mathrm{LD}_{50}-$ мінімальне $(112,0 \pm 26,2$ год), що нижче показників контролю, відповідно, на 10,0-15,0\% та 30,0\% (табл. 1).

Кореляційне відношення для виживання сперміїв за наростаючих доз лоратадину слабке $\left(\eta^{2}=0,141\right)$. Лоратадин знижує дихальну активність сперми, проте сила впливу на досліджуваний показник мала $\left(\eta^{2}=0,255\right)$. Однак наростаючі дози вказаної фармакологічної суб- станції зменшують відновну активність сперми. При цьому лоратадин у дозі $1 / 500 \mathrm{LD}_{50}$ знижує величину показника на $84,0 \%$, у дозі $1 / 100 \mathrm{LD}_{50}$ - на 98,0\% $(P<$ $0,05)$, а у разі додавання лоратадину на рівні $\mathrm{LD}_{50}$ 3ниження становило 80,0\% порівняно з контролем. Кореляційне відношення для відновної активності сперми за наростаючих доз лоратадину середньої сили $\left(\eta^{2}=0,581\right)$.

За дії наростаючих доз дезлоратадину $\left(1 / 500 \mathrm{LD}_{50}\right.$, $1 / 100 \mathrm{LD}_{50} \mathrm{i} \mathrm{LD}_{50}$ ) величина фізіологічного показника знижується, відповідно, на 5,3, 10,6 і 52,7\% (табл. 2). При цьому різниця між величинами контролю та за дози дезлоратадину $\mathrm{LD}_{50}$ статистично вірогідна $(P<0,05)$. Вплив наростаючих доз дезлоратадину на виживання сперміїв середній по силі $\left(\eta^{2}=0,400\right)$.

Виживання сперміїв та інтенсивність окисних процесів у спермі бугаїв за дії лоратадину $(n=3 ; M \pm m)$

Таблиия 1

\section{Показники}

Виживання сперміїв, год Споживання кисню, нг-атом $O /(0,1$ мл $\mathrm{C} \times$ хв $)$ Відновна активність, $\mathrm{mV} /(0,1$ мл $\mathrm{C} \times$ хв $)$

\begin{tabular}{ccc} 
& \multicolumn{2}{c}{ Умови інкубування сперми } \\
Контроль (ФСБ) & ФСБ $+1 / 500 \mathrm{LD}_{50}$ & ФСБ $+1 / 100 \mathrm{LD}_{50}$ \\
$160,0 \pm 26,1$ & $136,0 \pm 26,2$ & $144,0 \pm 19,6$ \\
$3,9 \pm 1,34$ & $3,1 \pm 0,87$ & $2,2 \pm 0,74$ \\
$2,5 \pm 0,82$ & $0,4 \pm 0,26$ & $0,05 \pm 0,01 *$
\end{tabular}

$\Phi \mathrm{C} 5+\mathrm{LD}_{50}$
$112,0 \pm 26,2$
$1,5 \pm 0,48$
$0,5 \pm 0,39$

Кореляційне відношення, $\eta^{2}$ 0,141

0,255

0,581

Примітка: * - різниця статистично вірогідна порівняно з контролем за $P<0,05$.

Табличя 2

Виживання сперміїв та інтенсивність окисних процесів у спермі бугаїв за дії дезлоратадину $(n=3 ; M \pm m)$

\section{Показники}

Виживання сперміїв, год

Споживання кисню,

нг-атом $O /(0,1$ мл $\mathrm{C} \times \mathrm{xв})$

Відновна активність,

$\mathrm{mV} /(0,1$ мл $\mathrm{C} \times$ хв $)$
Умови інкубування сперми
СБ $+1 / 500$ LD $_{50}$ ФСБ + 1/100 LD

Контроль (ФСБ)
$152,0 \pm 23,6$
$3,1 \pm 0,47$
$2,5 \pm 0,47$
$144,0 \pm 19,6$

$2,6 \pm 0,66$

$2,2 \pm 0,36$
$136,0 \pm 26,1$

$$
1,9 \pm 0,61
$$$$
1,5 \pm 0,10
$$

ФСБ $+\mathrm{LD}_{50}$

$72,0 \pm 19,6^{*}$

$0,6 \pm 0,25 * *$

$1,0 \pm 0,39$
Кореляційне відношення, $\eta^{2}$ 0,400

0,513

0,466

Примітка: * - різниця статистично вірогідна порівняно з контролем за $P<0,05, * *$ - за $P<0,01$.

Більшими змінами характеризуються величини дихальної та відновної активностей сперми за впливу вказаної фармакологічної субстанції. Інтенсивність споживання кисню спермою за умови додавання дезлоратадину знижується на 16,2\% за дози препарату $1 / 500 \mathrm{LD}_{50}$, на $38,8 \%$ - за дози препарату $1 / 100 \mathrm{LD}_{50}$ і на $80,7 \%$ порівняно з контролем за дози $\mathrm{LD}_{50}(P<0,05)$. Гальмування дихальної активності супроводжується зменшенням транспорту протонів та електронів зі сперміїв у позаклітинне середовище, що проявляється зниженням відновної активності за дози дезлоратадину $1 / 500 \mathrm{LD}_{50}$ на $12,0 \%$, за дози дезлоратадину $1 / 100 \mathrm{LD}_{50}-$ на $40,0 \%$ i за умови додавання препарату в дозі $\mathrm{LD}_{50}-$ на $60,0 \%$, порівняно з контролем. Вплив наростаючих доз дезлоратадину на дихальну та відновну активність сперми середній за силою (відповідно, $\eta^{2}=0,513$ і 0,466).

Таким чином, досліджені фармакологічні субстанції у спермі проявляють цитотоксичний вплив, який характеризується пониженою інтенсивністю окисних процесів, імовірно, зниженим функціонуванням ланцюга дихання мітохондрій і ресинтезом АТФ, що зумовлює втрату рухливості та зменшення тривалості виживання сперміїв.

\section{Висновки}

Цитотоксична дія лоратадину та дезлоратадину залежить від дози та характеризується порушенням окисних процесів сперми, що проявляється зменшеним споживанням кисню та пониженою відновною активністю. Обгрунтовуючи допустимий рівень вмісту препаратів у повітрі робочої зони, необхідно провести дослідження їх гонадотоксичного впливу на лабораторних тваринах.

\section{Бібліографічні посилання}

Almova, A.A., Begieva, M.B., 2012. Opredelenie toksicheskogo deystviya polimernykh materialov na osnove $\mathrm{N}, \mathrm{N}-$ diallilaminokislot [Definition of toxic action of polymeric materialson the basis of N,N-dasllyamino acids]. Fundamental'nye Issledovaniya 9, 539-541(in Russian).

Dmytrukha, N.N., 2013. Kultura kletok kak in vitro model v toksikologicheskikh issledovaniyakh [Cell culture as in vitro model in toxicology studies]. Medix. Anti-Aging. 3, 50-55 (in Russian).

Enayetallah, A.E., Puppala, D., Ziemek, D., Fischer, J.E., Kantesaria, S., Pletcher, M.T., 2013. Assessing the translat- 
ability of in vivo cardiotoxicity mechanisms to in vitro models using causal reasoning. BMC Pharmacol. Toxicol. 14, $46-58$.

Genovese, A., Patella, V., De Crescenzo, G., De Paulis, A., Spadaro, G., Marone, G., 1997. Loratadine and desethoxylcarbonyl-loratadine inhibit the immunological release of mediators from human fceri+cells. Clin. Exp. Allergy 27(5), $559-567$.

Karen, H.D., Patel, D.M., Jasakiya, A.R., Patel, C.N., 2013. Development of oral strip for loratadine and in vitro evaluation. Int. J. Pharm. Pharmacol. 2(8), 125-130.

McIntyre, B.S., Vancutsem, P.M., Treinen, K.A., Morrissey, R.E., 2003. Effects of perinatal loratadine exposure on male rat reproductive organ development. Reprod. Toxicol. 17(6), 691-697.

Muzyka, V.P., Atamanjuk, I.S., Chajkovs'ka, O.I., Panych, O.P., Sergijenko, O.I., Ostapiv, D.D., Jaremchuk, I.M., Kuzmina, N.V., Ostapiv, R.D., 2011. Do ocinjuvannja toksychnoi' dii' polimernyh vyrobiv z vykorystannjam test-ob'jektuspermii'v bugai'v [Evaluation of toxic effects of polymer products using the test object bull spermatozoa]. NaukovoTehnichnyj Bjuleten' Instytutu Biologii' Tvaryn i DNDKI Vetprepartiv ta Kormovyh Dobavok 12(3), 414-420 (in Ukrainian)

Nemkova, I.N., Guskova, T.A., Syubaev, R.D., Engalycheva, G.N., Vasiliev, A.N., 2013. Issledovanie in vitro tsitotoksicheskogo deystviya nesteroidnykh protivovospalitel'nykh sredstv, ispol'zuemykh $\mathrm{v}$ sostave kombinirovannykh lekarstvennykh preparatov [In vitro studi on cytotoxic effect of non-steroidal anti-inflammatory agents used in the composition of combined medicinal preparations]. Toksikologicheskiy Vestnik 5, 13-16 (in Russian).

Plokhinskiy, N.A., 1970. Biometriya [Biometry]. MSU, Moscow (in Russian).

Shtolts, K.F., Mosolova, I.M., Dronova, L.A., 1980. Amperometricheskoe opredelenie ferrotsianida $\mathrm{v}$ prisutstvii subkletochnykh struktur [Amperometric definition of ferrocyanide in the presence of subcellular structures]. Biokhimicheskie Metody. Nauka, Moscow, 147-150 (in Russian).

Soule, B.P., Simone, N.L., DeGraff, W.G., Choudhuri, R., Cook, J.A., 2010. Loratadine dysregulates cell cycle progression and enhances the effect of radiation in human tumor cell lines. Radiat. Oncol. 5(8), 1-12.

Wang, E., Casciano, C.N., Clement, R.P., Johnson, W.W., 2003. Evaluation of the interaction of loratadine and desloratadine with P-glycoprotein. DMD 29(8), 1080-1083.

Zaychenko, G.V., Yakovleva, L.V., Bryukhanova, T.O., Kolos, O.M., 2012. Suchasni protyalergichni preparaty: Klinikofarmakologichni ta farmakoekonomichni osoblyvosti [Modern antiallergic drugs: Clinical and pharmacological and pharmacoeconomical characteristics]. Ukrai'ns'kyj Medychnyj Chasopys 6, 134-136 (in Ukrainian).

Надійшла до редколегії 10.02.2014 